\title{
Mendudukkan Kembali Makna Kafir dalam al-Qur'an dan Konteksnya secara Teologis, Sosiologis, dan Politis
}

\author{
Revisiting the Meaning of Kafir in the Qur'an \\ and its Theological, Sociological, and Political Context
}

\author{
Moh. Isom Mudin', Nurul Laili Ahmadah', \\ Rahmat Ardi Nur Rifa Da'i ${ }^{3 凶}$, \& Muhamad Fawwaz Rizaka ${ }^{4}$ \\ ${ }^{1234}$ Universitas Darussalam (UNIDA) Gontor, Ponorogo, Indonesia \\ ranrifadai@mhs.unida.gontor.ac.id
}

Article history:

Submitted: November 23, 2020

Approved: June 2, 2021

Published: June 20, 2021

\begin{abstract}
To this day, the word kafir is still a hot topic to be discussed. Lately, the recommendation of the prohibition to mention kafir for non-Muslims to maintain religious harmony and peace in society has reaped pros and cons among Muslims. And in fact today, among the wider community, accusations of being infidels against a person or group are increasingly rife with the concept of kafir which is only understood about someone who believes in God other than Allah. This narrow understanding has given birth to existing conflicts, even though the concept of kafir has actually existed since the time of the Prophet and was not a problem among religious communities. Basically, the Qur'an itself has discussed the meaning of kafir and its levels. So to get a comprehensive understanding requires a relevant and in-depth approach. Through a qualitative library research, the researchers discuss the meanings of kafir contained in the Qur'an and the extent to which a person can be considered as an infidel according to the Qur'an as a guide for Muslims.
\end{abstract}

Keywords: al-Qur'an; infidel; interreligious relationship; Islam; types of kafir.

Abstrak: Sampai saat ini kata kafir masih menjadi perbincangan hangat. Belakangan ini anjuran pelarangan penyebutan kafir bagi non muslim untuk menjaga kerukunan dan ketentraman umat beragama menuai pro dan kontra di kalangan umat Islam. Dan faktanya, dewasa ini di kalangan masyarakat luas tuduhan kafir terhadap seseorang atau kelompok semakin marak dengan konsep kafir yang hanya dipahami tentang seseorang yang beriman kepada Tuhan selain Allah. Pemahaman yang sempit ini telah melahirkan konflik-konflik yang ada, padahal konsep kafir sebenarnya sudah ada sejak zaman Nabi dan tidak menjadi masalah di kalangan umat beragama. Pada dasarnya Al-Qur'an sendiri sudah membahas tentang pengertian kafir dan tingkatannya. Sehingga untuk mendapatkan pemahaman yang komprehensif diperlukan pendekatan yang relevan dan mendalam. Melalui penelitian pustaka kualitatif, peneliti membahas tentang makna kafir yang terkandung dalam Al-Qur'an dan sejauh mana seseorang dapat dianggap kafir menurut Al-Qur'an sebagai pedoman bagi umat Islam.

Kata kunci: al-Qur'an; hubungan antaragama; Islam; jenis-jenis kafir; kafir.

P-ISSN 1907-1191 E-ISSN 2540-9204 ㄷ 2021 Author(s).

Published by LP2M INSURI Ponorogo, this is an open access journal article licensed CC-BY-SA

DOI: 10.37680 /adabiya.v16i1.619 


\section{Pendahuluan}

Penggunaan kata kafir akhir-akhir ini kerap mengundang kontroversi dan dianggap mengganggu persaudaraan masyarakat sebangsa dan setanah air, ${ }^{1}$ seperti kasus diadilinya seorang kiai karena tuduhan penghinaan dengan melabeli kafir bagi orang yang tidak menunaikan shalat. ${ }^{2}$ Selain itu, ada juga kasus seorang ulama Mesir yang ditangkap karena penistaan agama setelah mengecap kafir dan tidak masuk surga bagi umat Kristen dan Yahudi. Pernyataan tersebut dinilai dapat meruntuhkan perdamaian masyarakat dan menimbulkan terjadinya konflik antar umat beragama. ${ }^{3}$ Bahkan secara naluriah, setiap umat beragama merasa terganggu dan tidak senang dengan sebutan kafir hingga tidak jarang di antara mereka yang membela diri dari tuduhan kafir sampai mempertaruhkan jiwanya. ${ }^{4}$

Berawal dari beberapa konflik-konflik keagamaan yang berada di beberapa negara memunculkan sebuah ide untuk menghapus penggunaan kata kafir dengan alasan demi menjaga kedamaian bangsa dan negara. Misalnya, di Indonesia sendiri ada intelektual muslim Achmad Munjid yang mendukung adanya penghapusan kata kafir untuk negara Indonesia. Menurutnya, negara Indonesia adalah negara demokrasi, negara yang lebih mengutamakan keadilan dan kedamaian masyarakat, sehingga tidak ada hal-hal yang sifatnya berkuasa berpayung agama apalagi menindas yang minoritas. ${ }^{5}$ Ditambah lagi, menurut Hasanudin Abdurakhman, Indonesia sendiri tidak dibangun atas dasar agama tertentu, bahkan kata Islam sendiri tidak ada dalam Undang-undang Dasar. Dengan adanya penghapusan kata tersebut, diharapkan ke-NKRI-an dan kebinekaan lebih terjaga, aman dan hidup dalam ketentraman. ${ }^{6}$

Dalam khazanah Islam, terma kafir pada hakikatnya telah ada sejak zaman Rasulullah saw. Hal ini bisa dibuktikan dengan banyaknya dalil-dalil dalam al-Qur'an yang menjelaskan tentang kafir, baik secara sisi pelakunya maupun perbuatannya. Namun terma itu tidak menjadi sebuah masalah seperti yang kita temui saat ini. Sentimen kata kafir itu muncul kurang lebih karena kurangnya pemahaman masyarakat umum mengenai masalah konsep kafir. Selain itu juga dikarenakan penempatan kata kafir yang tidak sesuai pada tempatnya dan kurang tepatnya cara penyampaian para pemuka agama terkini mengenai konsep kafir.

1 Fabian Januarius Kuwado, “Ini Kata PGI Soal Keputusan NU Tak Sebut Umat Non-Muslim Kafir," accessed October 1, 2019, https://nasional.kompas.com/read/2019/03/05/14154221/ini-kata-pgi-soal-keputusan-nutak-sebut-umat-non-muslim-kafir?page=all.

2 Hendri F. Isnaeni, "Sebut Kafir, Kiai Diadili," accessed October 2, 2019, https:/historia.id/agama/articles/sebut-kafir-kiai-diadili-P1B12.

${ }^{3}$ Maria Rita, "Sebut Kristen Dan Yahudi Kafir, Ulama Mesir Didakwa Menista Agama,” accessed October 4, 2019 , https://dunia.tempo.co/read/875068/sebut-kristen-dan-yahudi-kafir-ulama-mesir-didakwa-menistaagama/full\&view $=$ ok.

${ }^{4}$ Harifuddin Cadiwu, Konsep Kufr Dalam Al-Qur'an (Jakarta: PT Bulan Bintang, 1991), 9.

5 Achmad Munjid, "Demi Indonesia Yang Damai, Kata Kafir Memang Sebaiknya Dihapus," accessed October 4, 2019, http://theconversation.com/demi-indonesia-yang-damai-kata-kafir-memang-sebaiknya-dihapus113193.

6 Hasanudin Abdurakhman, "Kafir Dalam Konteks NKRI," accessed September 28, 2019, https://news.detik.com/kolom/d-4452513/kafir-dalam-konteks-nkri. Tentang bagaimana potensi konflik horizontal yang dipicu oleh sentimen agama belakangan ini, lihat antara lain Wahyu Hanafi Putra, and Dawam M. Rohmatulloh. "Bahasa dan Narasi Politik Kreatif; Kontestasi Merebut Kebenaran Islam dalam Demokrasi Digital 2019 di Indonesia." In Proceedings of Annual Conference for Muslim Scholars, vol. 3, no. 1, pp. 294-302. 2019. 
Dari latar belakang di atas, penulis menilai perlunya pembahasan kembali terkait konsep kafir $^{7}$ secara benar dengan merujuk kepada ayat-ayat dalam Al-Qur'an. Hal ini didasarkan karena kata kafir terlahir dari Al-Qur'an yang merupakan asas dan pemandu bagi umat Islam dalam mengarungi kehidupan. ${ }^{8}$ Maka, dalam artikel ini akan dibahas mengenai makna-makna kafir dan konsepnya dalam al-Qur'an serta tingkatan hingga sejauh mana seseorang bisa dianggap kafir. Untuk mempermudah jalannya penelitian, penulis menggunakan studi kepustakaan dalam bentuk kualitatif. Buku-buku yang berhubungan tema pembahasan dikaji dan dianalisis sedemikian rupa dengan menggunakan metode deskriptif-analisis.

\section{Definisi Kafir}

Istilah kafir berasal dari kata bahasa arab "kāfir"/ كافر yang merupakan turunan dari ka-fa-ra, yang secara bahasa memiliki beberapa makna, antara lain "lawan beriman, menutupi, tidak berterimakasih, dan membebaskan diri". ${ }^{9}$ Seorang petani dikatakan kafir karena mereka menutupi biji dengan tanah, begitu juga malam disebut kafir sebab pada saat gelap malam menutupi segala sesuatu. ${ }^{10}$ Kata kafir juga dimaknai dengan lawan dari iman. Jika iman bermakna kepercayaan dan pembenaran, maka kafir bermakna penolakan, menganggap bohong, dan pengingkaran. ${ }^{11}$ Dalam Kamus Besar Bahasa Indonesia, kafir diartikan sebagai orang yang tidak beriman kepada Allah dan Rasul-Nya, sedangkan kekafiran diartikan dengan perihal (yang bersifat atau berciri) kafir. $^{12}$

Dari uraian ini dapat dipahami kata kafir secara terminologi dimaknai dengan pembatal keimanan ${ }^{13}$ atau segala sesuatu yang bertentangan dengan iman, baik secara perkataan, perbuatan maupun kepercayaan. ${ }^{14}$ Kekafiran bisa dilihat dari tidak adanya pengakuan dan keimanan seseorang terhadap Rasul. Bisa juga dilihat dari tidak mengakui kabar (kebenaran) yang telah sampai padanya, hanya sekedar mempercayai atas kabar yang diterima sehingga tidak berpengaruh pada ketaatan secara lahir dan batin, dan tidak mencintai Allah serta mengagungkanNya. Hal ini dinamakan kafir karena menutupi kebenaran yang telah sampai kepadanya, seperti orang-orang fasik contohnya. ${ }^{15}$

Dalam al-Qur'an, istilah ini lebih banyak merujuk pada makna penolakan dan pendustaan terhadap apa yang dibawa oleh Rasulullah seperti dalam surat an-Nisa: 137, Ali Imran': 72, an-

\footnotetext{
${ }^{7}$ Sebagaimana antara lain dalam Muhammad Hariyadi and Lukman Nurhakim, "Wawasan Al-Qur'an Tenteng Kekafiran." Al-Burhan| Jurnal Kajian Ilmu dan Pengembangan Budaya Al-Qur'an 16, no. 2 (2016); Muhammad Nabiel Akbar, "Makna Kafir dalam Tafsir Al-Mishbah Karya M. Quraish Shihab." Universitas Muhammadiyah Surakarta, 2018; dan Muhammad Hamdan, "Filosofi Kafir dalam al-Qur'an: Analisis Hermeneutik Schleiermacher." Tashwirul Afkar 38, no. 02 (2020).

${ }^{8}$ Haikal Fadhil Anam, "Konsep Kafir Dalam Alquran: Studi Atas Penafsiran Asghar Ali Engineer," NALAR: Jurnal Peradaban Dan Pemikiran Islam 2, no. 2 (December 31, 2018): 89, https://doi.org/10.23971/njppi.v2i2.971.

${ }^{9}$ S. Askar, Kamus Al-Azhar (Jakarta: Senayan Abadi Publishing, 2009), 745; Ibnu al-Manzūr, Lisan Al-'Arab (Kairo: Dar al-Ma'arif, 1119), 3898.

${ }^{10}$ Ahmad Izzuddin Al-Bayanuni, Kafir Dan Indikasinya (Surabaya: PT Bina Ilmu, 1989), 2.

${ }^{11}$ Mohammed Emarah, Islam Dalam Pandangan Marxisme (Jakarta: Prenamedia Group, 2018), 10.

${ }^{12}$ Suharso dan Ana Retnoningsih, Kamus Besar Bahasa Indonesia (Semarang: Widya Karya, 2005), 211.

${ }^{13}$ Ibnu al-Manzeūr, Lisan Al-'Arab, 3897.

${ }^{14}$ Ahmad Ibnu Taimiyyah, Majmu' Al-Fatāwā (Madinah Munawwaroh: Mujamma'I al-Malik Fahdin li alTiba'ah al-Mushaf al-Syarif, 2004), Jilid 20, 86.

${ }^{15}$ Ab̄̄ Al-Qāsim Al-Husain bin Muhammad (al-Rāghib al-Asfahānī), Al-Mufrodāt Fi Gharībi Al-Qur'ān (t.t: Maktabatu Nazar Musthofa Al-Baz, 2009), 560.
} 
Nahl: 106, an-Nur: 55, al-Fath:29, al-Hujurat: 7 dan lain sebagainya. Pada umumnya, ayat-ayat tersebut di atas menegaskan bahwa orang kafir adalah orang yang menolak dan mendustakan keesaan Allah, kerasulan Nabi Muhammad dan syariah yang dibawanya. ${ }^{16}$

\section{Makna Kafir dalam al-Qur'an}

Dalam al-Qur'an, kata kafir disebut sebanyak 524 kali yang tersebar dalam 73 surat dari 114 surat yang ada dengan beragam maknanya. ${ }^{17}$ Apabila ditinjau secara seksama akan ditemukan bahwa al-Qur'an mengartikan kata kafir dalam bentuk fi'il madhi (kata kerja lampau, past tense) sebanyak 231 kali, dalam bentuk fi'il mudhori' (kata kerja sekarang dan akan datang, present continuous tense) diungkapkan sebanyak 68 kali dan dalam bentuk fi'il amr (kata kerja perintah) berjumlah 3 kali saja. Dalam bentuk lain, yaitu masdar sejumlah 64 kali, ism fa'il 157 kali dan ism tafdhil hanya sekali saja.

Kata "kufr" secara bahasa bermakna menutupi, seperti malam yang disebut kafir karena gelapnya menutupi segala sesuatu. ${ }^{18}$ Namun dalam al-Qur'an, ia memiliki makna yang banyak saat disandingkan dengan kata yang lain. Saat kata "kufr" disandingkan dengan "ni'mah", maka ia dimaknai dengan lawan dari kata "syukr" yang artinya tidak berterimakasih seperti firman Allah dalam surat Ibrahim ayat 7. Kata syukr dimaknai dengan menampakkan, membuka dan lawannya kufur yang artinya menyembunyikan dan menutupi. Inti dari syukur yaitu menggunakan sesuatu sesuai dengan tempat dan porsinya serta sesuai dengan kehendak yang memberikan. Maksudnya, jika seseorang mendapatkan kenikmatan maka ia harus merenungi apa yang didapatkan dari sang Maha Pemberi, kemudian memanfaatkannya semaksimal mungkin sesuai tujuannya. Namun, saat seseorang itu mengkufurinya maka kenikmatan itu dapat mengundang musibah yang melahirkan kemiskinan, rasa lapar, penyakit, takut dan cemas. ${ }^{19}$ Sedangkan kata kaffar dimaknai lebih dari tidak berterimakasih. Dalam surat Qaf ayat 24, kata كفّار (kaffar) merupakan bentuk hiperbola dari kata bermakna orang yang sangat banyak dan keras kekufurannya. Sedangkan kata عنيد 'anid adalah orang yang sangat keras kepala dan selalu menentang kebenaran, walaupun hal itu sudah jelas baginya.

Dari penjelasan di atas, telah tergambarkan dampak buruk dari sebuah kekufuran. Dampak itu adalah barang siapa yang sering melakukan kekufuran, lambat laun ia akan bersifat keras kepala menolak kebenaran yang dihadapinya yang akhirnya menjadikannya bersifat 'anid. Lebih jauh lagi, sifat keras kepala ini akan mengantarkannya pada terhalangi dari kegiatan yang positif, karena hakikatnya hanyalah kebenaran yang mampu mengantar pada kebajikan. Hingga akhirnya, hal ini bisa menjadikan seseorang menjadi seند mu'tanid, yang bersikap aniaya kepada orang lain serta menghalangi orang lain untuk menerima kebaikan dengan jalan menanamkan keraguan pada hati mereka. ${ }^{20}$

${ }^{16}$ Abī Al-Qāsim Al-Husain bin Muhammad (al-Rāghib al-Asfahān̄i), 714-16.

${ }^{17}$ Muhammad Fu'ād 'Abd al-Bāqī, Al-Mu'jam Al-Mufahras Li Alfāz Al-Qur'ān Al-Karīm (Beirut: Dar al-Fikr, 1981), 605-13.

${ }^{18}$ Ab̄̄ Al-Qāsim Al-Husain bin Muhammad (al-Rāghib al-Asfahān̄̄), 599.

${ }^{19}$ M. Quraish Shihab, Tafsir Al-Misbah (Jakarta: Lentera Hati, 2002), Vol. 16, 330.

${ }^{20}$ Shihab, Vol. 13, 39. 
Sedangkan dalam surat al-Fath ayat 29, terdapat dua kata كفار (kuffar) yang bermakna berbeda. Pertama, kalimat أشداء على الكفار (asyiddau ala kuffar) sering kali digunakan untuk berperilaku keras terhadap non-muslim. Padahal dalam al-Qur'an kata كافر (kafir) tidak selalu bermakna non-muslim, namun kafir memiliki beragam arti yang kesemuanya terhimpun dalam makna "Siapa yang melakukan aktivitas yang bertentangan dengan tujuan agama." Maka bisa saja seorang muslim dipandang kafir, jika ia melakukan aktivitas yang dipandang mengandung kedurhakaan, meskipun pandangan tersebut bukan dari pakar-pakar hukum. Jika demikian berarti sikap keras dan tegas tidak hanya diperuntukkan kepada non-muslim. ${ }^{21}$ Selanjutnya makna kuffar yang kedua adalah para penanam biji. Mereka disebut kuffar karena mereka menutupi (menanam) biji dengan tanah. ${ }^{22}$

Terdapat sebuah ayat yang mencakup tiga makna kafir yaitu pada surat Ali Imran ayat 97 yang menjelaskan tentang pelaksanaan ibadah haji. Makna tiga kata kafir itu adalah tidak bersyukur atas nikmat yang diberikan atau disebut dengan kikir, durhaka dan tidak mengakui ajaran Islam. Hal ini bisa dilihat dari sikap dan perilaku seseorang yang tidak mau melaksanakan kewajiban haji. Apabila ia tidak percaya akan kewajiban ini, maka bisa disebut kafir karena tidak mengakui ajaran Islam. Jika ia mengakui kewajiban ini, tapi tidak mau melaksanakannya padahal ia mampu, maka ia termasuk golongan orang yang durhaka. Kemudian, jika ia mencari dalih untuk menunda-nundanya padahal ia mampu melaksanakan ibadah haji, maka ia termasuk orang kafir dalam arti tidak mensyukuri nikmat Allah Swt. yagn telah diberikan kepadanya. ${ }^{23}$ Dari keseluruhan ayat kafir yang ada dalam Al-Qur'an, ternyata tidak seluruhnya membahas tentang kafir dalam artian teologi. Selanjutnya setelah ini pembahasan hanya akan difokuskan dalam perspektif teologi.

Pada umumnya, orang melihat kekafiran hanya sebagai ketidakpercayaan dan tidak melihat bahwa keengganan menuruti perintah Tuhan juga adalah suatu bentuk kekafiran juga. ${ }^{24}$ Hal penting yang harus digaris bawahi di sini adalah dalam beriman kepada Allah keimanan itu tidak dipisahkan dengan ketundukan dan kepatuhan kepada perintah-Nya, sedangkan keengganan dan sikap keras kepala daripada mengikuti jalan yang diinginkan dan dikehendaki Allah adalah suatu bentuk kekafiran. ${ }^{25}$

Jika menelaah mengenai makna kafir dalam Al-Qur'an secara teologi, maka akan dapat diklasifikasikan menjadi beberapa golongan. Yang pertama adalah kafir yang dimaknai dengan pengingkaran secara i'tiqad (kepercayaan). Pengingkaran ini seperti ketidakpercayaan bahwa Allah itu Tuhan yang Maha Esa, pengingkaran bahwa Nabi Muhammad saw. adalah utusan Allah, dan segala ketidakpercayaan terhadap hal metafisik. Salah satu contoh pengingkaran ini terdapat dalam surat Al-Maidah ayat 73, yaitu para kaum Yahudi dan Nasrani yang mengingkari bahwa Nabi Muhammad saw. adalah utusan Allah. Dan di antara mereka ada yang mengimani utusan

${ }^{21}$ Shihab, Vol. 12, 560.

${ }^{22}$ Abī Al-Qāsim Al-Husain bin Muhammad (al-Rāghib al-Asfahānī), 560.

${ }^{23}$ Shihab, Vol. 2, 198.

${ }^{24}$ Syed Muhammad Naquib Al-Attas, Islam and Secularism (Kuala Lumpur: ISTAC, 1993), 65.

${ }^{25}$ Khalif Muammar, Islam Dan Pluralisme Agama (Kuala Lumpur: Percetakan Mesbah SDN BHD, 2013), 131. 
Allah, namun tidak mengimani Allah sebagai Tuhan. ${ }^{26}$ Kaum Yahudi beriman terhadap Nabi Musa a.s. dan kitab Taurat, namun mengingkari Nabi Isa a.s. dan kitab Injil. Sedangkan agama Nasrani mengimani Nabi Isa dan kitab Injil, namun mengingkari Nabi Muhammad saw. dan AlQur'an. Mereka disebut sebagai seorang yang kafir, karena hanya mengimani sebagian dan mengingkari sebagian lainnya padahal mereka mengetahui kebenaran sesungguhnya. ${ }^{27}$

Kedua adalah kafir yang dimaknai dengan pengingkaran secara lisan terhadap Allah, Rasulullah, kitab yang diturunkan-Nya, serta hukum yang telah di tetapkan-Nya. Seperti yang dijelaskan dalam surat Yunus ayat 2, yaitu mereka yang mempertanyakan bagaimana bisa ayatayat itu bisa turun kepada Nabi Muhammad, padahal ia bukanlah seorang yang terbanyak hartanya dan bukan juga yang paling senior di antara mereka. Hingga akhirnya hal ini menjadi bahan cemohan atas Nabi Muhammad. Mereka menuduh Nabi Muhammad sebagai seorang penyihir disebabkan beliau menyampaikan ayat Al-Qur'an sedangkan ayat-ayat itu sangat mempesona bahkan hingga menjadikan seseorang meninggalkan agama nenek moyang mereka bagaikan -menurut orang musyrikin itu- orang-orang yang tersihir. ${ }^{28}$ Mencaci Rasulullah merupakan sebuah perbuatan yang membatalkan keimanan karena menyebabkan kekufuran lahir batin. $^{29}$

Selain itu, masih banyak ayat yang mengulas mengenai makna kafir dengan artian pengingkaran secara lisan. Ayat-ayat tersebut di antaranya yaitu al-Baqarah 26; al-A'raf 90; arRa'd 7, 27, dan 43; Ibrahim 1; Maryam 73; al-Furqan 4 dan 32; an-Naml 67; al-Ankabut 12; Saba 3,7,31 dan 43; Shad 4; Fussilat 26 dan 29; al-Ahqaf 7 dan 11; al-Qamar 8; dan an-Naba 40.

Ketiga, kafir juga dimaknai dengan pengingkaran secara perbuatan terhadap Allah, Rasulullah, kitab yang diturunkan-Nya, serta hukum yang telah ditetapkan-Nya. Hal ini seperti yang tercantum dalam surat al-An'am ayat 70, Ayat ini menjelaskan tentang orang-orang yang menjadikan agama Allah sebagai permainan dan olok-olokan, bahkan menghinanya saat disampaikannya ajaran agama ini kepada mereka. ${ }^{30}$

Selain itu, masih banyak ayat-ayat yang mengulas mengenai makna kafir dalam artian pengingkaran melalui perbuatan di antaranya yang terdapat pada beberapa surat yaitu al-Baqarah 34, 39, 98, 109, 171, 212, 254, 257; Ali Imran 54, 86, 149, 151, 167, 178; an-Nisa 137 dan 150; al-Maidah 17, 41, 57, 68, 72. dan 73; al-An'am 25 dan 70; al-A'raf 15, 35, 36, dan 65; at-Taubah 37 dan 54; Hud 27; Yusuf 87; an-Nahl 106; al-Kahfi 106; Shad 2 dan 74; az-Zumar 32 dan 59; Ghafir 4; al-Ahqaf 3; Muhammad 3. 12. dan 25; al-Fath 26; al-Mumtahanah 13; as-Shaf 8; alMunafiqun 3; at-Taghabun 10; al-Buruj 19; al-Bayyinah 1 dan 6; dan ayat-ayat lainnya.

Toshihiko Izutsu berpendapat bahwa istilah kafara dalam konteks teologi pertama bermakna "tidak bersyukur" bukan dalam pengertian bersyukur tentang kebaikan orang lain, namun bersyukur di sini adalah atas kebaikan-kebaikan Allah. Karena dalam pandangan islam,

${ }^{26}$ Moh Isom Mudin, "Pluralisme Agama: Akar Dan Justifikasi Al-Qur'an,” AL-RASIKH: Jurnal Hukum Islam 07, no. 02 (2017), https://ejournal.iaidalwa.ac.id/index.php/rasikh/article/view/59.

${ }^{27}$ Abi Ja'far Muhammad Ibn Jarīr At-Tabārī, Jāmi'u Al-Bayān 'an Ta'Wīl 'Ayi Al-Qur'Ān (Beirut: Dar alFikr, 2005), Jilid 4, Juz 6, 7-9.

${ }^{28}$ Shihab, Jilid 4, Juz 6, 7-9; Abi Ja’far Muhammad Ibn Jarīr At-Tabārī, Jilid 7, Juz 11, 97-100.

29 Abdul Aziz bin Muhammad bin Ali al-Abdul Lathif, Keyakinan, Ucapan, Dan Perbuatan Pembatal Keimanan (Jakarta: Darul Haq, 2017), 211.

${ }^{30}$ Abi Ja' far Muhammad Ibn Jarīr At-Tabārī, Jilid 5, Juz 7, 269. 
Allahlah yang menciptakan makhluk dan alam semesta serta mencukupi kebutuhannya. ${ }^{31}$ Dengan demikian, wajar saja jika Allah Swt. memerintahkan hamba-Nya untuk bersyukur kepada-Nya. Karena Allah Swt. tidak berwujud materi dan tidak bisa dilihat, maka ada sebagian manusia yang mengingkari keberadaan-Nya dan perintah-Nya. Dari sini dapat kita lihat pergeseran makna dari "tidak bersyukur" kepada "tidak percaya". ${ }^{32}$

Izutsu melalui pendekatan semantiknya memahami kata "kufr" dengan kata-kata kunci lainnya seperti "fisq", "dzulm”, "fajr”, "isyraq”, "nifaq" dan "iman”. Dari analisis semantik itu, ia mengambil kesimpulan bahwa kata "kufr" adalah salah satu konsep etis keagamaan yang akhirnya ia simpulkan menjadi lima konsep dalam al-Qur'an yaitu: pertama, ditinjau dari ilmu bahasa arti dasar kata kafara adalah "menyembunyikan". Hal ini berkenaan dengan pemberian dan penerimaan kebajikan. Kata kafara diartikan juga "menutupi", yakni "mengabaikan dengan sengaja kebaikan yang seharusnya diterima oleh seseorang", yang kemudian "menjadi tidak bersyukur". Kedua, Al-Qur'an memberikan penekanan bahwa Allah Swt. sebagai sang Maha Kuasa telah melimpahkan rahmat dan kebajikan kepada makhluk-Nya. Sudah semestinya sebagai makhluk ciptaan Tuhan bersyukur atas limpahan tersebut yang diberikan selama hidupnya di dunia. Dengan begitu, manusia akan disebut kafir jika bersikap tidak bersyukur dan tidak berterima kasih atas apa-apa yang telah Tuhan berikan kepadanya atau bahkan menentangnya.

Ketiga, sikap menentang dan tidak berterima kasih akan karunia Allah Swt. diungkapkan dengan cara yang sangat radikal yakni dengan takdzib atau menciptakan kebohongan terhadap Tuhan, nabi-nabi-Nya, dan wahyu yang diturunkan-Nya. Keempat, dengan demikian, kata kufur merupakan lawan kata dari iman (percaya). Sebagaimana dalam al-Qur'an kata kafir merupakan lawan kata dari muslim atau mukmin. Sehingga terlihat bahwa kufr terus menerus kehilangan makna aslinya yaitu "rasa tak berterima kasih", dan terus menerus dimaknai dengan "tidak percaya". Kelima, sebagai kata yang menolak anugerah Tuhan atas keimanan dan kenikmatan, perilaku dan sikap kufr diwujudkan dengan cara khusus seperti kecongkakan, kesombongan, kepongahan (istakhbara dan istaghni). Sikap ini merupakan lawan kata yang tepat dan bertentangan langsung dengan gagasan taqwa sebagai unsur pokok dalam agama Islam. ${ }^{33}$

\section{Sebab-sebab Terjadinya Kekafiran}

Para ulama, khususnya ahli Tafsir, sepakat berpendapat bahwa manusia lahir ke dunia membawa fitrah bertuhan, beriman dan menjadi muslim. ${ }^{34}$ Kesepakatan ini berlandaskan pada surat al-A'raf ayat 172 yang menjelaskan tentang pengakuan manusia atas rububiyahnya kepada Tuhan dengan firman-Nya, "Bukankah Aku adalah Tuhan, Penguasa dan Pengatur kalian?" seraya mereka menjawab, "Benar, kami bersaksi atas diri kami dengan penuh keyakinan dan kerelaan bahwa

31 Hamid Fahmy Zarkasyi et al., "IBN RUSHD'S INTELLECTUAL STRATEGIES ON ISLAMIC THEOLOGY," Jurnal Ilmiah Islam Futura 20, no. $1 \quad$ (February 29, 2020): 19, https://doi.org/10.22373/jiif.v20i1.5786.

32 Toshihiko Izutsu, Relasi Tuhan Dan Manusia (Yogyakarta: Tiara Wacana, 1997), 14-15. $187-89$.

33 Toshihiko Izutsu, Konsep-Konsep Etika Religius Dalam Al-Qur'an (Yogyakarta: Tiara Wacana, 1993),

34 Agus Setyawan, "Dakwah Yang Menyelamatkan: Memaknai Ulang Hakikat Dan Tujuan Da'wah Islamiyah," Al-Adabiya: Jurnal Kebudayaan Dan Keagamaan 15, no. 02 (November 9, 2020): 189-99, https://doi.org/10.37680/adabiya.v15i02.487. 
Engkau adalah Tuhan dan Pencipta kami, tidak ada Tuhan selain Engkau dan kami mengikrar kesaksian ini."

Ayat di atas menjelaskan bahwa manusia telah berjanji di hadapan Tuhan untuk mengakui keberadaan-Nya sebagai Tuhan dan bersedia untuk mentaati segala perintah dan larangan-Nya. Dengan dianugerahi akal, manusia dapat melaksanakan segala amanah yang diberikan sebagai bentuk pengabdian dirinya sebagai hamba dan memikirkan tanda-tanda kebesaran Tuhan di alam ini. ${ }^{35}$ Dengan begitu manusia akan berfikir bahwa Tuhan adalah Sang Pencipta Alam Semesta dan mengendalikannya. Dari sini bisa dipahami bahwa setiap manusia mempunyai potensi untuk bertuhan, beriman, dan menjadi Muslim.

Jika setiap manusia pada dasarnya beriman dan bertuhan maka mengenai kekafiran tentunya terdapat faktor-faktor yang menyebabkan manusia bisa menjadi kafir. ${ }^{36}$ Terdapat tiga unsur pokok yang dapat menyebabkan kekafiran, yakni: pertama, Keyakinan (al-I'tiqad). Fakor keyakinan yang menjadikan seseorang kafir seperti pengingkaran atas keberadaan Tuhan sebagai Sang Pencipta, pengingkaran atas kewajiban dan larangan yang sudah ditetapkan oleh Allah Swt., dan menghalalkan yang haram ataupun sebaliknya. Mereka inilah termasuk orang-orang kafir dan sudah berlaku hukum-hukum Islam atas orang kafir kepada mereka.

Kedua, ucapan (al-Lisan). Di antara ucapan seseorang yang bisa masuk ke golongan orang kafir yaitu mengingkari mengingkari akidah Islam, ucapan yang mengandung penghinaan terhadap agama, mengingkari keadilan Tuhan, dll. ${ }^{37}$ Jika yang mengatakan kata ingkar itu adalah orang kafir, maka ia telah menunjukkan kekafirannya. Jika yang mengucapkan adalah orang Islam, maka ia menjadi orang yang murtad. Namun jika ungkapan yang diucapkan oleh orang yang tidak berakal dan karena terpaksa maka orang tersebut tidak dihukumi kafir, disebabkan adanya uzur.

Ketiga, perbuatan (al-'Amal). Perbuatan seseorang yang menyebabkan kekafiran yaitu semua perbuatan berkenaan dengan adanya keyakinan yang diekspresikan bisa menjadi kafir seperti merobek-robek mushaf disertai penghinaan, dan seorang muslim menggantungkan salib pada dada disertai rasa pengagungan dan rasa cinta. ${ }^{38}$

\section{Jenis-jenis Kekafiran}

Banyak jenis kafir yang dibicarakan dalam Al-Qur'an. Namun jika ditinjau dari perspektif akidah, setidaknya jenis kafir adalah sebagai berikut: ${ }^{39}$

Pertama, kafir al-inkar, yaitu mengingkari secara hati dan lisan terhadap ketauhidan Allah $^{40}$ atau kekafiran dalam arti pengingkaran terhadap eksistensi Tuhan, Rasul dan seluruh ajaran yang dibawa. Dari tinjauan secara akidah, mereka adalah jenis kafir yang tidak percaya

${ }^{35}$ Muhammad Rasyīd Riḍā, Tafsīr Al-Qur'ān Al-Hakīm; Tafsīr Al-Manār (Kairo: Dar Al-Manar, 1373), Jilid IX, 387.

${ }^{36}$ Harifuddin Cadiwu, 90.

37 Taqiyuddin Abi Bakar Bin Muhammad al-Hushni al-Khusaini Al-Damaskusi, Kifayatu Akhyar Fi Khilli Ghayatil Ikhtishar Fi Al-Fiqh Al-Syafi'i (Damaskus: Dar al-Basyair, 2001), 586.

${ }^{38}$ Ahmad Izzuddin Al-Bayanuni, 7-10.

${ }^{39}$ A. Syarif Yahya, Fikih Toleransi (Yogyakarta: Aswaja Presindo, 2016), 93.

${ }^{40}$ Ibnu al-Manzūur, 3898. 
akan adanya keberadaan Tuhan dan semua hal-hal yang bersifat metafisik ${ }^{41}$ dan ia merupakan jenis kafir terbesar. ${ }^{42}$ Bentuk kafir seperti ini hanya mempercayai hal-hal yang bersifat empiris dan materi. Jenis ini dapat kita temukan dalam firman Allah surat an-Nisa ayat 150-151 yang menjelaskan tentang orang-orang yang mengingkari Allah dan Rasul-Nya, serta mereka yang ingin memisahkan antara keduanya dengan beriman kepada salah satu dan mengingkari yang lain. Sesungguhnya mereka termasuk golongan orang yang kafir karena seorang mukmin adalah yang mengimani semua kebenaran yang ada. ${ }^{43}$ Karakteristik yang sangat dominan dari jenis kafir seperti ini orientasinya adalah duniawi yang cenderung hedonis. Segala pikiran dan harta dan waktu yang mereka habiskan hanya untuk kenikmatan duniawi semata. ${ }^{44}$ Salah satu ayat yang menyebutkan sifat mereka adalah surat An-Nahl ayat 107.

Kedua, kafir al-juhud yaitu kekafiran yang mengakui akan kebenaran Tuhan dan Rasul-Nya dalam hati tetapi mengingkarinya secara lisan ${ }^{45}$ seperti kekafiran iblis, ${ }^{46}$ dan pengingkaran lainnya yang dapat dilihat pada surat al-Baqarah ayat 89. Dalam ayat tersebut menjelaskan tentang bagaimana orang-orang Yahudi mengingkari apa yang telah diturunkan Allah yaitu alQur'an untuk membenarkan kitab Taurat yang ada pada mereka. Padahal sebelumnya mereka sendiri yang meminta kepada Allah sebelum datangnya Rasulullah yang membawa al-Qur'an, akan kedatangannya untuk menghadapi musuh mereka kaum musyrik. Namun setelah al-Qur'an turun, mereka justru mengingkarinya ${ }^{47}$ Kafir juhud tidak jauh berbeda dengan kafir inkar, yakni sama-sama tidak mengakui Tuhan sebagai kebenaran yang mutlak. Perbedaan dari kedua jenis terdapat pada posisi pengingkarannya. Yang pertama benar-benar mengingkari kebenaran yang ada, dan yang kedua pengingkaran berdasarkan kesombongan atau keangkuhan dan semacamnya yang pada dasarnya dalam hati si pengingkar mengetahui kebenaran yang ada dan nyata itu. ${ }^{48}$ Jadi karakteristik jenis kafir ini sama seperti kafir inkar.

Ketiga, kafir al-nifaq, adalah jenis kafir yang berkebalikan dengan kufr juhud yaitu kekafiran yang mengakui secara lisan tetapi mengingkari secara hati atau keyakinan. ${ }^{49}$ Dalam Islam, jenis kafir ini sering disebut dengan munafik. Seperti halnya dapat dilihat dalam surat alMaidah ayat 41 yang menjelaskan tentang orang-orang kafir yang munafik. Mereka menyatakan bahwa diri mereka Islam namun hati mereka kosong akannya. Maka keislaman mereka tidak lebih dari sekedar kata-kata lisan saja. ${ }^{50}$ Watak dasar mereka ada tiga yaitu khianat, ingkar janji, dusta, dan riya. ${ }^{51}$ Di antara karakteristik orang munafik yang digambarkan dalam al-Qur'an yaitu (1) Berkepribadian goyah dan tidak berprinsip, khususnya dalam hal akidah; (2) Bertopeng untuk menutupi keaslian diri, dan tidak segan mengumbar sumpah palsu; (3) Pengecut, tidak memiliki rasa tanggung jawab dan tidak mengakui kesalahan; (4) Berdusta saat berkata, mengingkari saat berjanji, dan berkhianat saat diberi amanat; (5) Pebuatan yang dilakukan hanya untuk pamrih dan

\footnotetext{
${ }^{41}$ Harifuddin Cadiwu, 105.

${ }^{42}$ Ab̄̄ Al-Qāsim Al-Husain bin Muhammad (al-Rāghib al-Asfahānī), 559.

${ }^{43}$ Abi Ja'far Muhammad Ibn Jarīr At-Tabārī, Jilid 4, Juz 6, 9.

${ }^{44}$ A. Syarif Yahya, 107.

45 A. Syarif Yahya, 121.

46 Ibnu al-Manzūur, 3898.

${ }^{47}$ Abi Ja'far Muhammad Ibn Jarīr At-Tabārī, Jilid 1, Juz 1, 527.

${ }^{48}$ Harifuddin Cadiwu, 123.

${ }^{49}$ Harifuddin Cadiwu, 124.

${ }^{50}$ Abi Ja' far Muhammad Ibn Jarīr At-Tabārī, Jilid 4, Juz 6, 291.

${ }^{51}$ A. Syarif Yahya, 94.
} 
riya'; (6) memiliki sikap malas dan acuh tak acuh; dan (7) Suka membuat fitnah dan menyebarkan berita bohong. ${ }^{52}$ Secara khusus, karakter mereka disebut dalam surat al-Munafiqun.

Keempat, kafir as-syirk, yaitu menduakan atau menyembah selain Tuhan. Syirik termasuk kekafiran karena perbuatan ini mengingkari keesaan Tuhan. ${ }^{53}$ Mereka adalah orang yang menodai secara esensial bagi Allah, yaitu keesaan yang berarti pula merusak kesempurnaan-Nya. ${ }^{54}$ Seperti yang dapat dilihat dalam firman Allah pada surat Al-Maidah ayat 73 yang menjelaskan tentang orang kafir adalah orang yang menganggap bahwa Allah itu adalah Tuhan ketiga dari tiga Tuhan. ${ }^{55}$

Kelima, kafir al-irtidad (al-riddah). Istilah irtidad atau al-riddah secara etimologi dimaknai "berbalik kembali". ${ }^{56}$ Dan secara terminologi agama dimaknai dengan kembali kepada kekafiran, dari keadaan beriman, baik iman itu didahului oleh kekafiran lain (sebelumnya) ataupun tidak. ${ }^{57}$ Jenis juga bisa dimaknai sebagai seorang yang secara lahir memproklamasikan diri memeluk agama lain atau masih mengaku Islam tetapi melakukan penistaan pokok-pokok ajaran Islam. Contohnya adalah seperti kaum yang diperangi Abu Bakar r.a. karena menentang syariat zakat. ${ }^{58}$ Jenis kafir ini dapat ditemukan pada firman Allah surat an-Nisa ayat 137 yang menjelaskan tentang orang yang beriman lalu kafir lalu beriman lagi, dan kafir lagi. Inilah yang dimaksud dengan konsep murtad, yaitu kembali kepada kekafiran dari keadaan beriman. ${ }^{59}$ Kekafiran jenis ini banyak terjadi, misalnya, seperti mereka yang berlatarbelakang perkawinan beda agama.

Setelah pembahasan mengenai klasifikasi kafir yang ditinjau dari perspektif akidah, maka kemudian akan dibahas klasifikasi kafir ditinjau dari perspektif fiqih atau syariah. Tinjauan dari perspektif fiqih ini bisa menjadi landasan dalam bermuamalah atau bergaul dalam kehidupan sehari-hari. Berikut klasifikasi kafir ditinjau dari perspektif fikih: ${ }^{60}$

Pertama, kafir harbi, yaitu sekolompok non-Muslim yang memerangi kaum Muslimin dan halal darahnya untuk ditumpahkan/dibunuh. Jenis ini tergambarkan dalam surat al-Maidah ayat 33. Menurut Yusuf al-Qardawi, istilah kafir harbi adalah golongan yang tinggal di wilayah Muslim dan menyatakan permusuhan terhadap kaum Muslim beserta para pemimpin dan tidak mengakui Negara Islam. ${ }^{61}$ Maka golongan kafir harbi adalah golongan kafir yang menampakkan permusuhan dan menyerang kaum Muslim. ${ }^{62}$ Kaum Muslim mengambil sikap tegas terhadap golongan kafir ini karena mereka memusuhi dan memerangi Islam. ${ }^{63}$

Kedua, kafir dzimmi, yaitu golongan kafir kitabi yang dianggap tidak membahayakan akidah umat Islam. Mereka diperbolehkan hidup dengan aman di wilayah kekuasaan Islam

${ }^{52}$ A. Syarif Yahya, 127.

${ }^{53}$ Harifuddin Cadiwu, 136.

${ }^{54}$ A. Syarif Yahya, 94.

${ }^{55}$ Abi Ja'far Muhammad Ibn Jarīr At-Tabārī, Jilid 4, Juz 6, 386.

${ }^{56}$ Harifuddin Cadiwu, 150

${ }^{57}$ M. Husayn al-Tabātabā'̄i, Al-Mīzān Fi Al-Tafsìr Al-Qur'ān (Beirut: Mua'ssaat al-A'lami li al 'Matbu'ah, n.d.), Jilid 5, 114.

${ }^{58}$ A. Syarif Yahya, 94.

${ }^{59}$ Abi Ja'far Muhammad Ibn Jarīr At-Tabārī, Jilid 4, Juz 5, 398.

${ }^{60}$ A. Syarif Yahya, 96.

${ }^{61}$ Yusuf al-Qardhawi, Fikih Jihad: Sebuah Karya Monumetal Terlengkap Tentang Jihad Menurut Al-Qur'an Dan Sunnah, Terj. Irfan Maulana Hakim (Bandung: Mizan, 2010), 751.

${ }^{62}$ Rāshid al-Ghanūshī, Huqūq Al-Muwātanah: Huqūq Ghair Al-Muslim Fi Al-Mujtama Al-Islamı̄ (Virginia: Ma'had al-'Alam li al-Fikr al-Islami, 1993), 60.

${ }^{63}$ Hamka, Prinsip Dan Kebijakan Dakwah Islam (Jakarta: Pustaka Panjimas, 1984), 165. 
dengan hak dan kewajiban yang diatur oleh pemimpin Islam. Dalam hal ini, diwajibkan bagi mereka membayar pajak (jizyah) kepada pemerintah Islam. ${ }^{64}$

Ketiga, kafir muahid. Mereka sebenarnya adalah harbi, namun mereka mengadakan perjanjian damai dengan pemerintahan atau Negara Islam. ${ }^{65}$ Maka hak dan kewajiban mereka diatur dan dilindungi oleh syariat dan perjanjian yang disepakati. ${ }^{66}$ Mereka adalah golongan kafir yang bersikap baik, menjalin hubungan yang harmonis terhadap kaum Muslim serta tidak terlibat dalam memusuhi mereka. ${ }^{67}$ Dan keempat, kafir musta'in yaitu non muslim yang tinggal bermukim sementara di wilayah kekuasaan muslim. Dalam hal perlindungan mereka sama dengan mu'ahid dan dzimmi. ${ }^{68}$

Secara umum, kategorisasi di atas bisa dipahami termasuk dalam ranah sosiologis-politis bukan teologis. Orang yang menyangkal tugas dan ajaran yang dibawa oleh Nabi Muhammad saw. Memang disebut kafir secara teologis. Tetapi secara sosial dan politis, semua haram darahnya, kecuali kafir harbi yang jelas-jelas menyatakan permusuhan dan dalam kondisi peperangan. Oleh karena itu, bagian berikut ini akan membahas tentang kafir dari sudut pandang sosial dan politik.

\section{Kafir dalam Perspektif Sosial-Politik}

Islam mengakui adanya kemajemukan atau pluralitas, baik dalam bidang kultur, ras dan agama sebagai kehendak Sang Khalik Allah Swt. Dalam pandangan teologis Islam, akidah merupakan asas yang fundamental dalam membedakan antara muslim dengan selainnya. Dengan perbedaan teologis tersebut sebagai bukti bahwa Islam tidak mentoleransi dan tidak menyatakan bahwa semua agama itu sama. ${ }^{69}$ Sedangkan dalam aspek sosial, Allah Swt. telah menjelaskan bahwa umat Islam agar selalu berbuat baik dan berperilaku adil kepada selainnya, sebagaimana dalam surat al-Mumtahanah ayat 8. Ayat ini turun ketika Qutailah -mantan istri Abu Bakar yang masih musyrik- datang kepada putrinya; Asma' dengan membawa beberapa hadiah. Asma' menolak dan bahkan melarang ibunya masuk ke rumahnya. Kemudian saudari seayahnya; Aisyah bertanya kepada Rasulullah dan turunlah ayat tersebut. ${ }^{70}$ Berdasarkan ayat ini, setiap muslim diperintahkan untuk bersikap baik dan adil ke semua manusia, ${ }^{71}$ termasuk kepada orang-orang yang tidak mengakui agama Islam selama mereka tidak mencela, memerangi atau menindas para pemeluknya. $^{72}$

${ }^{64}$ A. Syarif Yahya, 96.

${ }^{65}$ Yusuf al-Qardawi, Fatwa-Fatwa Kontemporer, Terj. As'ad Yasin (Jakarta: Gema Insani Press, 1999), Jilid 2, 967-968.

${ }^{66}$ A. Syarif Yahya, 97.

${ }^{67}$ Rāshid al-Ghanūshī, 60-61.

${ }^{68}$ A. Syarif Yahya, 97.

${ }^{69} \mathrm{Ja}$ 'far Abd al-Salām, Al-Tasāmuh Fi Al-Fikri Al-Islamī (Kairo: Rabitah al-Jami'ah al-Islamiyah, 2005), 167.

${ }^{70}$ A. Syarif Yahya, 99.

${ }^{71}$ Asna Istya Marwantika, "Potret Dan Segmentasi Mad'u Dalam Perkembangan Media Di Indonesia," AlAdabiya: Jurnal Kebudayaan Dan Keagamaan 14, no. 01 (August 29, 2019): 1-14, https://doi.org/10.37680/adabiya.v14i01.100.

${ }^{72}$ Yūsuf Qarḍawī, Minoritas Non- Muslim Di Dalam Masyarakat Islam, Terj. Muhammad Baqir (Mesir: Maktabah Wahbah, 1994), 16. 
Orang-orang non muslim yang tidak memerangi apalagi terikat konstitusi yang melindungi segenap komponen bangsa, wajib dipergauli dengan baik sebagai saudara sebangsa. ${ }^{73}$ Dalam ayat itu digunakan kata "al-birr" (berbuat baik), yaitu suatu kata yang biasanya dipakai dalam hubungan seorang anak dengan kedua orang tuanya dalam berbentuk berbakti kepada keduanya. Maka adil adalah memberi hak tanpa sedikitpun menguranginya, sedangkan berbuat baik adalah kita memberikan sebagian hak kita kepada mereka. ${ }^{74}$

Dalam surat Ali Imran ayat 28 juga menjelaskan bahwa ayat ini tidak melarang seorang muslim untuk berteman dengan non muslim, dengan syarat tidak berlebihan dan mengesampingkan saudara seagama. Sebab bagaimanapun, kewajiban seorang muslim kepada muslim adalah memberikannya dua hak yaitu hak saudara sebangsa dan seagama. Sementara bagi non muslim hanya berkewajiban memberi satu hak yaitu saudara sebangsa. ${ }^{75}$

Lebih lanjut, dalam al-Qur'an surat Hud ayat 118 dan Yunus ayat 99 dijelaskan bahwa Islam memerintahkan umatnya untuk bersikap toleran terhadap agama lain, karena perbedaan keyakinan atau agama juga merupakan bagian dari ketetapan-Nya. Oleh karena itu, umat Islam dilarang untuk memaksakan suatu agama kepada orang lain, apalagi memaksakan seseorang agar memeluk agama Islam (surat al-Baqarah ayat 256). ${ }^{76}$

Dalam kitab Tafsir Munir, Wahbah Zuhaily membagi muwalah (bersahabat atau mengangkat pemimpin/penolong) dengan non muslim menjadi tiga: pertama, muwalah dengan hati yang ridho atas kekufuran mereka, seperti mengikuti ibadah mereka atau berkeyakinan seperti keyakinan mereka. Muwalah seperti ini diharamkan karena ridha kepada kekufuran termasuk dalam kufur; kedua, muwalah dalam hal duniawi dengan berbuat kebaikan secara zahir, seperti membantu membangun rumah, kerja bakti, musyawarah desa dan lain sebagainya diperbolehkan dalam Islam, bahkan dianjurkan demi menjaga kerukunan dalam bermasyarakat; dan ketiga, muwalah dengan mengikat hubungan erat dengan non muslim, seperti berteman akrab melebihi keakraban sesama muslim tidaklah menyebabkan kekufuran namun hal ini dilarang. Pelarangan ini dilandaskan karena hal ini bisa mendorong seorang muslim untuk ridha kepada kekufuran secara perlahan-lahan. ${ }^{77}$

Syariat Islam memberikan kebebasan kepada seluruh manusia dalam hal berakidah, sebagai wujud penghormatan bahwa mereka juga manusia yang punya hak dan eksistensi hidup. Rasulullah bersabda. "Barangsiapa yang membunuh orang yang sudah melakukan perjanjian, maka ia tidak akan dibenarkan mencium bau surga."78 Dalam konteks tersebut, dapat dimengerti bahwa Islam merupakan agama yang mengakui keberadaan keyakinan lain dan memberikan perlindungan terhadap hak-hak keyakinan lain untuk untuk hidup dan berkembang. Di antara perlindungan itu adalah dengan menjaga orang kafir dan mengayominya dalam melakukan ibadah. ${ }^{79}$ Dengan menempatkan status non muslim secara proporsional, maka seorang muslim

\footnotetext{
${ }^{73}$ A. Syarif Yahya, 99.

${ }^{74}$ Abdul Jamil Wahab, Harmoni Di Negeri Seribu Agama (Jakarta: PT Gramedia, 2015), 99.

75 A. Syarif Yahya, 100.

${ }^{76}$ Abdul Jamil Wahab, 93.

77 Wahbah Zuhaily, Tafsir Al-Munir Fi Al-'Aqidah Wa as-Syari'ah Wa Al-Manhaj (Damaskus: Dar al-Fikr,

${ }^{78}$ Muhammad bin Isma’il al-Bukhārī, Șaḥ̄ḥ Al-Bukhārī, Juz I (Beirut: Dār al-Tuqun al-Najāh, 1422), Vol. IV,

${ }^{79}$ Mohammed Emarah, 15.
} 2009) 
bisa hidup berdampingan dan bahkan bekerja sama dalam urusan duniawi dengan tetap meyakini adanya batas yang memisahkan terutama dalam hal keyakinan dan peribadatan.

\section{Simpulan}

Terma kafir pada dasarnya bukanlah sebuah hal yang perlu dipermasalahkan. Kata ini sesungguhnya telah ada sejak zaman Rasulullah dan fakta historis kata ini tidak pernah menimbulkan masalah. Jika ada yang mengatakan bahwa terma kafir ini kontroversial hingga mengakibatkan peperangan antar umat yang terjadi, itu bukanlah hal yang benar, karena hakikatnya bukanlah karena faktor teologis namun lebih kepada faktor sosial politik. Dalam ranah teologi, konsep kafir tidak hanya sebagai ketidakpercayaan, namun juga keengganan menuruti perintah Tuhan juga adalah suatu bentuk kekafiran juga. Sedangkan dalam ranah sosial, Islam telah menempatkan status kafir secara proporsional dengan mengakui keberadaan keyakinan lain dan tetap bermuamalah dengan baik kepada mereka selama mereka tidak memerangi Islam. Timbulnya masalah adalah karena kurangnya pemahaman masyarakat umum mengenai konsep kafir dalam al-Qur'an dan disebabkan oleh kesalahan penempatan kata ini yang tidak sesuai dengan konteks dan tempatnya.

Dengan berlandaskan dari jenis-jenis kafir di atas, terutama dalam tinjauan syariah dan dalam konteks sosial-politik, terdapat alat untuk mengklasifikasikan seseorang, apakah dia termasuk golongan kafir atau tidak sehingga tidak menjadikan seorang muslim mudah dalam menjatuhkan tuduhan kafir terhadap seseorang atau sebuah kelompok. Tanpa alat yang proporsional tersebut, kecerobohan dalam menilai kafir justru memberikan gambaran buruk terhadap wajah Islam di hadapan umat lain, karena dianggap mengandung unsur hinaan dan mengganggu kedamaian umat beragama.

\section{Daftar Pustaka}

Abd al-Bāqī, Muhammad Fu'ād. Al-Mu'jam Al-Mufahras Li Alfāz Al-Qur'ān Al-Karīm. Beirut: Dar al-Fikr, 1981.

Abd al-Salām, Ja'far. Al-Tasāmuh Fi Al-Fikri Al-Islamī. Kairo: Rabitah al-Jami'ah al-Islamiyah, 2005.

Abdurakhman, Hasanudin. "Kafir Dalam Konteks NKRI." Accessed September 28, 2019. https://news.detik.com/kolom/d-4452513/kafir-dalam-konteks-nkri.

Akbar, Muhammad Nabiel. "Makna Kafir dalam Tafsir Al-Mishbah Karya M. Quraish Shihab." Universitas Muhammadiyah Surakarta, 2018.

al-Attas, Syed Muhammad Naquib. Islam and Secularism. Kuala Lumpur: ISTAC, 1993.

al-Bayanuni, Ahmad Izzuddin. Kafir Dan Indikasinya. Surabaya: PT Bina Ilmu, 1989.

al-Bukhārī, Muhammad bin Isma'il. Șaḥịh Al-Bukhārī. Juz I. Beirut: Dār al-Tuqun al-Najāh, 1422 .

al-Damaskusi, Taqiyuddin Abi Bakar Bin Muhammad al-Hushni al-Khusaini. Kifayatu Akhyar Fi Khilli Ghayatil Ikhtishar Fi Al-Fiqh Al-Syafi'i. Damaskus: Dar al-Basyair, 2001.

al-Ghanūshī, Rāshid. Huqūq Al-Muwātanah: Huqūq Ghair Al-Muslim Fi Al-Mujtama Al-Islamī. Virginia: Ma'had al-'Alam li al-Fikr al-Islami, 1993. 
al-Manzūr, Ibnu. Lisan Al-'Arab. Kairo: Dar al-Ma'arif, 1119.

al-Qardhawi, Yusuf. Fatwa-Fatwa Kontemporer, Terj. As'ad Yasin. Jakarta: Gema Insani Press, 1999.

. Fikih Jihad: Sebuah Karya Monumetal Terlengkap Tentang Jihad Menurut Al-Qur'an Dan Sunnah, Terj. Irfan Maulana Hakim. Bandung: Mizan, 2010.

. Minoritas Non- Muslim Di Dalam Masyarakat Islam, Terj. Muhammad Baqir. Mesir: Maktabah Wahbah, 1994.

al-Tabātabā'̄̄, M. Husayn. Al-Mīzān Fi Al-Tafsīr Al-Qur'ān. Beirut: Mua'ssaat al-A'lami li al 'Matbu'ah, n.d.

Anam, Haikal Fadhil. "Konsep Kafir Dalam Alquran: Studi Atas Penafsiran Asghar Ali Engineer." NALAR: Jurnal Peradaban Dan Pemikiran Islam 2, no. 2 (December 31, 2018): 89. https://doi.org/10.23971/njppi.v2i2.971.

Askar, S. Kamus Al-Azhar. Jakarta: Senayan Abadi Publishing, 2009.

Bin Ali al-Abdul Lathif, Abdul Aziz bin Muhammad. Keyakinan, Ucapan, Dan Perbuatan Pembatal Keimanan. Jakarta: Darul Haq, 2017.

Bin Muhammad (al-Rāghib al-Asfahān̄̄), Abī Al-Qāsim Al-Husain. Al-Mufrodāt Fi Gharībi AlQur'ān. t.t: Maktabatu Nazar Musthofa Al-Baz, 2009.

Emarah, Mohammed. Islam Dalam Pandangan Marxisme. Jakarta: Prenamedia Group, 2018.

Ibn Jarīr At-Tabārī, Abi Ja'far Muhammad . Jāmi'u Al-Bayān 'an Ta'Wīl 'Ayi Al-Qur'Ān. Beirut: Dar al-Fikr, 2005.

Ibnu Taimiyyah, Ahmad. Majmu' Al-Fatāwā. Madinah Munawwaroh: Mujamma'I al-Malik Fahdin li al-Tiba'ah al-Mushaf al-Syarif, 2004.

Cadiwu, Harifuddin. Konsep Kufr Dalam Al-Qur'an. Jakarta: PT Bulan Bintang, 1991.

Hamdan, Muhammad. "Filosofi Kafir dalam al-Qur'an: Analisis Hermeneutik Schleiermacher." Tashwirul Afkar 38, no. 02 (2020). https://doi.org/10.51716/ta.v38i02.25

Hamka. Prinsip Dan Kebijakan Dakwah Islam. Jakarta: Pustaka Panjimas, 1984.

Hariyadi, Muhammad, and Lukman Nurhakim. "Wawasan Al-Qur'an Tenteng Kekafiran." AlBurhan| Jurnal Kajian Ilmu dan Pengembangan Budaya Al-Qur'an 16, no. 2 (2016). https://journal.ptiq.ac.id/index.php/alburhan/article/view/81

Isnaeni, Hendri F. "Sebut Kafir, Kiai Diadili." Accessed October 2, 2019. https:/historia.id/agama/articles/sebut-kafir-kiai-diadili-P1B12.

Izutsu, Toshihiko. Konsep-Konsep Etika Religius Dalam Al-Qur'an. Yogyakarta: Tiara Wacana, 1993. . Relasi Tuhan Dan Manusia. Yogyakarta: Tiara Wacana, 1997.

Kuwado, Fabian Januarius. "Ini Kata PGI Soal Keputusan NU Tak Sebut Umat Non-Muslim Kafir." $\quad$ Accessed $\quad$ October 2019. https://nasional.kompas.com/read/2019/03/05/14154221/ini-kata-pgi-soal-keputusan-nutak-sebut-umat-non-muslim-kafir?page=all.

Marwantika, Asna Istya. "Potret Dan Segmentasi Mad'u Dalam Perkembangan Media Di Indonesia." Al-Adabiya: Jurnal Kebudayaan Dan Keagamaan 14, no. 01 (August 29, 2019): 1-14. https://doi.org/10.37680/adabiya.v14i01.100.

Muammar, Khalif. Islam Dan Pluralisme Agama. Kuala Lumpur: Percetakan Mesbah SDN BHD, 
2013.

Mudin, Moh Isom. "Pluralisme Agama: Akar Dan Justifikasi Al-Qur'an." AL-RASIKH: Jurnal $\begin{array}{lllll}\text { Hukum Islam } & 07, & \text { no. } & 02 & \text { (2017). }\end{array}$ https://ejournal.iaidalwa.ac.id/index.php/rasikh/article/view/59.

Munjid, Achmad. "Demi Indonesia Yang Damai, Kata Kafir Memang Sebaiknya Dihapus." Accessed October 4, 2019. http://theconversation.com/demi-indonesia-yang-damai-katakafir-memang-sebaiknya-dihapus-113193.

Putra, Wahyu Hanafi, and Dawam M. Rohmatulloh. "Bahasa dan Narasi Politik Kreatif; Kontestasi Merebut Kebenaran Islam dalam Demokrasi Digital 2019 di Indonesia." In Proceedings of Annual Conference for Muslim Scholars, vol. 3, no. 1, pp. 294-302. 2019.

Riḍā, Muhammad Rasyīd. Tafsīr Al-Qur'ān Al-Hakìm; Tafsīr Al-Manār. Kairo: Dar Al-Manar, 1373.

Rita, Maria. "Sebut Kristen Dan Yahudi Kafir, Ulama Mesir Didakwa Menista Agama." Accessed October 4, 2019. https://dunia.tempo.co/read/875068/sebut-kristen-dan-yahudikafir-ulama-mesir-didakwa-menista-agama/full\&view $=$ ok.

Setyawan, Agus. "Dakwah Yang Menyelamatkan: Memaknai Ulang Hakikat Dan Tujuan Da'wah Islamiyah." Al-Adabiya: Jurnal Kebudayaan Dan Keagamaan 15, no. 02 (November 9, 2020): 189-99. https://doi.org/10.37680/adabiya.v15i02.487.

Shihab, M. Quraish. Tafsir Al-Misbah. Jakarta: Lentera Hati, 2002.

Suharso dan Ana Retnoningsih. Kamus Besar Bahasa Indonesia. Semarang: Widya Karya, 2005.

Wahab, Abdul Jamil. Harmoni Di Negeri Seribu Agama. Jakarta: PT Gramedia, 2015.

Yahya, A. Syarif . Fikih Toleransi. Yogyakarta: Aswaja Presindo, 2016.

Zarkasyi, Hamid Fahmy, Amal Fathullah Zarkasyi, Tonny Ilham Prayogo, and Rahmat Ardi Nur Rifa Da'i. "IBN RUSHD'S INTELLECTUAL STRATEGIES ON ISLAMIC THEOLOGY." Jurnal Ilmiah Islam Futura 20, no. 1 (February 29, 2020): 19. https://doi.org/10.22373/jiif.v20i1.5786.

Zuhaily, Wahbah. Tafsir Al-Munir Fi Al-'Aqidah Wa as-Syari'ah Wa Al-Manhaj. Damaskus: Dar al-Fikr, 2009. 